\title{
Effect of Five Nitrogen Sources Applied at Four Rates to Pangola Grass Sod Under Humid Tropical Conditions ${ }^{1,2}$
}

\author{
Jacinto Figarella, Fernando Abruña, and \\ José Vicente-Chandler ${ }^{3}$
}

\section{INTRODUCTION}

The effect of nitrogen rates on yield and composition of Napier, Para, Pangola, Guinea, Star, and Congo grasses have been determined under humid tropical conditions in Puerto Rico by Vicente-Chandler, Abruña, Silva, Caro, and Figarella $(1,5,6,8,9,10,11,12)$. Caro and Vicente-Chandler $(2,3,4)$ also have determined the effect of fertilizer levels on beef production and carrying capacity of Napier and Pangola grass pastures under these conditions.

Vicente-Chandler and Figarella (7) found that ammonium sulfate, sodium nitrate, ammonium nitrate, urea, and ammonium hydroxide, applied at the rate of 600 pounds of nitrogen per acre yearly to Napier grass harvested by cutting close to the ground so that the fertilizer was applied to essentially bare soil, resulted in similar yields of forage. Urea and ammonium hydroxide, however, were less efficient providers of nitrogen as shown by lower recovery rates in the forage.

Little information is available, however, on the efficiency of the various sources of nitrogen when applied to pastures of sod grasses, such as Pangola, under humid tropical conditions.

The present study determined the effects on forage yield and composition and on soil acidity, of five nitrogen sources applied at four rates to Pangola grass sod managed so as to simulate grazing conditions over a 3-year period.

\section{MATERIALS AND METHODS}

The experiment was carried out near Orocovis, at an elevation of about 2,000 feet with a mean annual temperature of about $75^{\circ} \mathrm{F}$. The soil is deep red, acid, well-drained Humatas clay (Ultisol) on a 25-percent slope: The upper 6-inch layer of soil had 4.0 percent organic matter, a $\mathrm{pH}$ of 5.3 , and

1 Manuscript submitted to Editorial Board September 28, 1971.

2 This paper covers research conducted cooperatively between the Soil and Water Conservation Research Division, Agricultural Research Service, USDA, and the Agricultural Experiment Station, College of Agricultural Sciences, Mayagüez Campus, University of Puerto Rico, Río Píedras, P.R.

${ }^{3}$ Analytical Chemist, Soil Scientist, and Soil Scientist-Project Leader, respectively SWCRD, ARS, USDA, Rio Piedras, P.R. 
16.5 meq. of exchange capacity with 10.4 meq. of exchangeable bases per $100 \mathrm{~g}$. of soil. Bulk density of the soil was $1.1 \mathrm{~g}$./cc.

The following treatments were tested using a split-plot design with four replications: Approximate nitrogen levels (main plots) -0, 170, 340, and 510 pounds per acre yearly-nitrogen sources (subplots)-urea, ammonium sulfate, ammonium nitrate, urea mixed with calcium carbonate in equal parts, and ammonium-nitrate-lime (ANL).

At each application, samples from all nitrogen sources were analyzed for nitrogen content and the precise quantity of this nutrient applied was determined.

Individual plots were $10 \times 15$ feet, surrounded by ditches to prevent fertilizer from washing into adjoining plots. A pure stand of Pangola grass was established and maintained in all plots.

The upper 6-inch layer of soil in all plots was limed to about $\mathrm{pH} 6.0$ at start of the experiment. Blanket additions of 150 pounds of $P$ (from triple superphosphate) and 600 pounds of $\mathrm{K}$ (from $\mathrm{K}_{2} \mathrm{SO}_{4}$ ) per acre yearly were made to all plots. All fertilizer was applied in six equal applications yearly corresponding to the number of cuttings.

The grass in all plots was cut every 60 days to about 6 inches from the ground and the fertilizer applied on the remaining dense sod, which was similar to that of well-managed Pangola grass pastures immediately after grazing.

The forage produced by each plot at each cutting was weighed and samples analyzed for dry matter and nitrogen content. Crude protein was calculated by multiplying the nitrogen content by 6.25 . Samples from all second-year cuttings were composited by plots and analyzed for phosphorus, calcium, potassium, and magnesium.

At the end of 3 years the soil in all plots receiving 510 pounds of nitrogen per acre yearly from the different sources was sampled and analyzed for pH, exchangeable calcium + magnesium, and exchangeable aluminum.

\section{RESULTS AND DISCUSSION}

Annual rainfall totalled 61.6, 101.0, and 86.6 inches during the 3 years of experimentation and was fairly well-distributed. The following tabulation shows average monthly rainfall for the 3 -year period.

$\begin{array}{lrlr}\begin{array}{c}\text { Rainfall } \\ \text { (inches) }\end{array} & \text { Jainfall } \\ \text { July } & 4.1 & \text { January } & \begin{array}{c}\text { Rarch) } \\ \text { (inches }\end{array} \\ \text { August } & 5.3 & \text { February } & 6.3 \\ \text { September } & 5.6 & \text { March } & 4.1 \\ \text { October } & 8.8 & \text { April } & 4.7 \\ \text { November } & 14.9 & \text { May } & \mathbf{7 . 9} \\ \text { December } & 5.1 & \text { June } & \mathbf{1 1 . 0} \\ \end{array}$

Total.................................83.2 
Yields of dry matter and of protein, and protein content of the forage increased markedly with nitrogen rates, irrespective of nitrogen source (table 1).

The various nitrogen sources did not appreciably affect yields of dry forage except that ammonium sulfate produced higher yields than urea at the 340-pound nitrogen rate (table 1).

Ammonium sulfate applications at both the 340- and 510-pound nitro-

TABLE 1.-Effect of five sources of nitrogen applied al 8 rales on dry forage and protein yields, and protein content of Pangola grass, and on recovery of fertilizer nitrogen in the forage over a 3 -year period at Orocovis

\begin{tabular}{lccccc}
\hline Nitrogen source & $\begin{array}{c}\text { Nitrogen } \\
\text { applied per } \\
\text { acre yearly }\end{array}$ & $\begin{array}{c}\text { Yields of dry } \\
\text { forage per } \\
\text { acre yearly }\end{array}$ & $\begin{array}{c}\text { Protein } \\
\text { content }\end{array}$ & $\begin{array}{c}\text { Yields of } \\
\text { protein per } \\
\text { acre yearly }\end{array}$ & $\begin{array}{c}\text { Recovery of } \\
\text { fertitizer } \\
\text { nitrogen }\end{array}$ \\
\hline O N & Pounds & Pounds & Percent & Postrds & Percent \\
Urea & 0 & $4,732 \mathrm{~b}$ & $5.9 \mathrm{~b}$ & $278 \mathrm{~b}$ & - \\
Ammonium sulfate & 170 & $11,932 \mathrm{a}$ & $6.8 \mathrm{a}$ & $811 \mathrm{a}$ & $50.0 \mathrm{a}$ \\
Ammonium nitrate & 171 & $12,396 \mathrm{a}$ & $6.9 \mathrm{a}$ & $851 \mathrm{a}$ & $53.8 \mathrm{a}$ \\
Urea + CaCO & 158 & $11,300 \mathrm{a}$ & $6.7 \mathrm{a}$ & $761 \mathrm{a}$ & $46.1 \mathrm{a}$ \\
ANL & 171 & $11,634 \mathrm{a}$ & $6.6 \mathrm{a}$ & $770 \mathrm{a}$ & $50.0 \mathrm{a}$ \\
& & & $6.8 \mathrm{a}$ & $849 \mathrm{a}$ & $53.2 \mathrm{a}$ \\
O N & 0 & $5,398 \mathrm{c}$ & $6.4 \mathrm{~d}$ & $345 \mathrm{c}$ & \\
Urea & 340 & $15,608 \mathrm{~b}$ & $7.7 \mathrm{bc}$ & $1,209 \mathrm{~b}$ & $40.6 \mathrm{~b}$ \\
Ammonium sulfate & 342 & $17,669 \mathrm{a}$ & $8.6 \mathrm{a}$ & $1,527 \mathrm{a}$ & $55.3 \mathrm{a}$ \\
Ammonium nitrate & 334 & $16,298 \mathrm{ab}$ & $8.1 \mathrm{ab}$ & $1,312 \mathrm{~b}$ & $46.4 \mathrm{~b}$ \\
Urea + CaCO & 316 & $16,083 \mathrm{ab}$ & $7.3 \mathrm{c}$ & $1,172 \mathrm{~b}$ & $48.8 \mathrm{~b}$ \\
ANL & 342 & $16,405 \mathrm{ab}$ & $7.9 \mathrm{~b}$ & $1,297 \mathrm{~b}$ & $44.4 \mathrm{~b}$ \\
& & & & & \\
O N & 0 & $4,882 \mathrm{~b}$ & $6.2 \mathrm{~d}$ & $303 \mathrm{~d}$ & - \\
Urea & 510 & $18,085 \mathrm{a}$ & $8.9 \mathrm{c}$ & $1,603 \mathrm{c}$ & $40.8 \mathrm{~b}$ \\
Ammonium sulfate & 513 & $18,604 \mathrm{a}$ & $10.2 \mathrm{a}$ & $1,899 \mathrm{a}$ & $49.7 \mathrm{a}$ \\
Ammonium nitrate & 501 & $18,286 \mathrm{a}$ & $9.6 \mathrm{~b}$ & $1,749 \mathrm{~b}$ & $46.1 \mathrm{ab}$ \\
Urea + CaCO & 474 & $18,488 \mathrm{a}$ & $8.8 \mathrm{c}$ & $1,632 \mathrm{bc}$ & $44.9 \mathrm{ab}$ \\
ANL & 513 & $19,010 \mathrm{a}$ & $9.3 \mathrm{bc}$ & $1,770 \mathrm{ab}$ & $45.8 \mathrm{ab}$ \\
\hline
\end{tabular}

gen rates produced forage with a higher protein content than the other nitrogen sources, except ammonium nitrate at the 340-pound nitrogen rate. Also, ammonium nitrate produced forage with a higher protein content than did urea $+\mathrm{CaCO}_{3}$ at both the 340- and 510-pound nitrogen rates, and higher than urea at the 510-pound nitrogen rate. ANL produced forage with a higher protein content than did urea $+\mathrm{CaCO}_{3}$ at the 340 pound nitrogen level (table 1).

Ammonium sulfate applications at the 340-pound nitrogen level produced more protein than did any of the other sources. At the 510-pound 
nitrogen rate, ammonium sulfate applications produced more protein than did the other nitrogen sources with the exception of ANL, and ammonium. nitrate and ANL produced more protein than did urea (table 1).

At the 340-pound nitrogen rate, ammonium sulfate was a more efficient provider of nitrogen than any of the other sources, as shown by a higher recovery of fertilizer nitrogen in the forage (table 1). At this nitrogen rate, 55.3 percent of the nitrogen applied as ammonium sulfate was recovered in the forage, compared to an average of 43.3 percent for all other sources. Ammonium sulfate was also a more efficient provider of nitrogen than urea at the 510-pound nitrogen rate.

The various sources applied at the rate of 510 pounds of nitrogen per acre yearly did not appreciably affect the phosphorus, potassium, calcium, or magnesium content of the forage (table 2 ).

TABLE 2.-Effecl of five sources of nitrogen applied at the rale of about 510 pounds of nitrogen per acre yearly on the composition of Pangola grass forage cut every 60 days over a 1-year period at Orocovis

\begin{tabular}{lrccc}
\hline \multirow{2}{*}{$\begin{array}{c}\text { Nitrogen } \\
\text { source }\end{array}$} & \multicolumn{4}{c}{ Percent dry weight composition of forage } \\
\cline { 2 - 5 } & Phosphorus & Potassium & Calcium & Magnesium \\
\hline Urea & 0.13 & 2.52 & 0.53 & 0.15 \\
Ammonium sulfate & .15 & 2.35 & .53 & .18 \\
Ammonium nitrate & .14 & 2.69 & .55 & .19 \\
Urea $+\mathrm{CaCO}_{3}$ & .16 & 2.42 & .51 & .18 \\
ANL & .14 & 2.78 & .58 & .22 \\
\hline
\end{tabular}

The following tabulation shows the effect of five nitrogen sources applied at the rate of about 510 pounds of nitrogen per acre yearly over a 3-year period on the acidity of the upper 6 inches of soil.

\begin{tabular}{lcc}
\hline Nitrogen source & $\mathrm{pH}$ & Excbangeable $\mathrm{Ca}+\mathrm{Mg}$ \\
\hline & & (meg./100 8. of soil) \\
No nitrogen applied & 5.5 & 9.3 \\
Urea & 4.8 & 7.2 \\
Ammonium sulfate & 4.5 & 5.1 \\
Ammonium nitrate & 4.9 & 7.3 \\
Urea + CaCO & 5.2 & 10.2 \\
ANL & 5.5 & 11.0 \\
\hline
\end{tabular}

Ammonium sulfate applications resulted in highest surface soil acidity and lowest exchangeable $\mathrm{Ca}+\mathrm{Mg}$ contents, followed by ammonium nitrate and urea, while urea $+\mathrm{CaCO}_{3}$ and ANL resulted in acidity and exchangeable base levels similar to those of the no-nitrogen plots. 
Heavy ammonium sulfate applications sharply increased the exchangeable aluminum content of the soil profile, while ANL applications maintained the exchangeable aluminum content at levels similar to those of the no-nitrogen plots (see fig. 1,A).

Ammonium sulfate applications decreased $\mathrm{pH}$ and exchangeable bases in the upper 12 inches of soil, while ANL applications maintained $\mathrm{pH}$ and exchangeable bases at levels similar to those of the no-nitrogen plots (figs. 1B and C).

It is apparent that ammonium sulfate was generally the most efficient source of nitrogen and urea least, although the difference was not great.
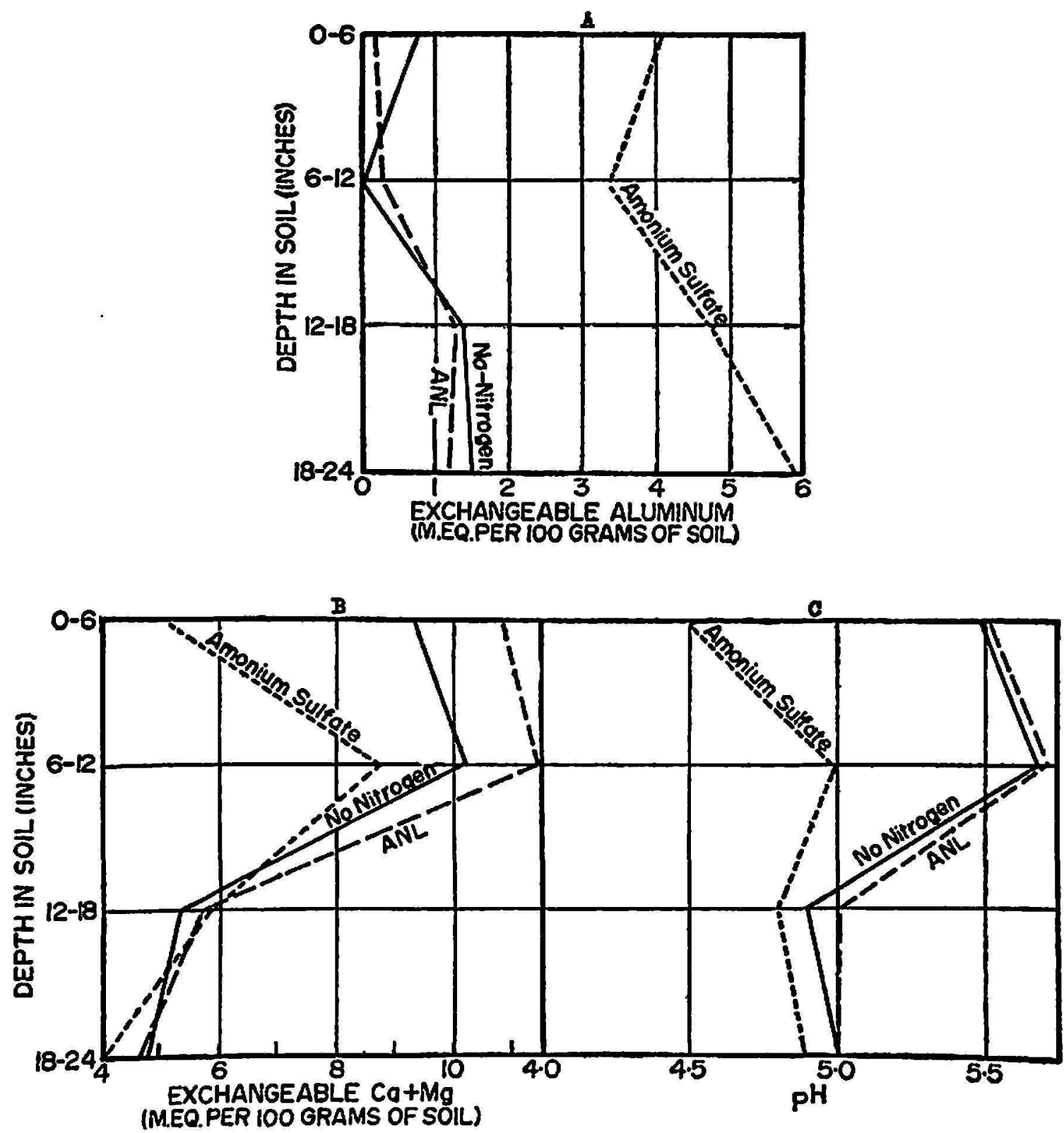

FIG. 1 (A, B and C).-The effect of two nitrogen sources applied at the rate of 510 pounds of nitrogen per acre yearly over a 3 -year period on soil acidity at 4 depths in 8 Humstas clay. 
Also, mixing urea or ammonium nitrate with lime did not affect the efficiency with which these sources provided nitrogen to the grass, and provided insurance against increasing soil acidity which farmers may later be reluctant to correct by heavy liming.

In final analysis, cost per unit of nitrogen from the different sources, including cost of the lime required to neutralize their residual acidity, is the determining factor in deciding which nitrogen source to use.

\section{SUMMARY}

The effects of applying ammonium sulfate, urea, ammonium nitrate, urea $+\mathrm{CaCO}_{3}$, and ammonium-nitrate-lime (ANL) at the rate of 0,170 , 340 , and 510 pounds of nitrogen per acre yearly to a Pangola grass pasture growing on a Ultisol under humid tropical conditions were determined over a 3-year period.

Although the differences were not marked, ammonium sulfate was generally the most efficient and urea the least efficient provider of nitrogen to the Pangola grass pastures. The various nitrogen sources did not affect the phosphorus, potassium, calcium, or magnesium content of Pangola grass.

Ammonium sulfate applications, and to a lesser extent urea and ammonium nitrate, increased exchangeable aluminum and decreased $\mathrm{pH}$ and exchangeable base content of the soil. Mixing lime with urea or ammonium nitrate did not affect their efficiency as suppliers of nitrogen to the grass, yet maintained soil acidity at levels similar to those of plots receiving no nitrogen.

\section{RESUMEN}

Se determinó el efecto de las aplicaciones de sulfato amónico, urea, nitrato amónico, urea + $\mathrm{CaCO}_{3}$ y nitrato amónico con cal a razón de 0, 170, 340 y 510 libras de nitrógeno por acre al año a pastos de yerba Pangola sembrados en un Ultisol bajo condiciones típicas de las regiones tropicales húmedas durante un periodo de 5 años.

Aunque las diferencias no fueron marcadas, el sulfato amónico fue en general la fuente de nitrógeno más eficaz y la urea la menos eficaz para los pastos de Pangola.

Las distintas fuentes de nitrógeno no afectaron el contenido en fósforo, potasio, calcio o magnesio de la Pangola.

Las aplicaciones de sulfato amónico, y en menor grado las de urea y nitrato amónico, aumentaron el contenido de aluminio intercambiable en el suelo y bajaron el $\mathrm{pH}$ y el contenido de bases intercambiables. La eficiencia de la urea y el nitrato amónico en suplir nitrógeno a la yerba no disminuyó al éstos mezclarse con cal, lográndose con esta mezcla mantener la acidez del suelo a niveles similares a los de las parcelas que no se abonaron con nitrógeno.

\section{LITERATURE CITED}

1. Caro-Costas, R., Abruña, F., and Figarella, J., Effect of nitrogen rates, harvest interval and cutting heights on yields and composition of Star grass in Puerto Rico, J. Agr. Univ. P.R. 56(3): 267-79, 1972.

2. - , and Vicente-Chandler, J., Effect of fertilization on carrying capacity and beef produced by Napier grass pastures, Agron. J., 53: 204-5, 1961. 
3. - and Vicente-Chandler, J., Effect of heavy rates of fertilization on beef production and carrying capacity of Napier grass pastures over five consecutive years of grazing under humid tropical conditions, J. Agr. Univ. P.R. 56(3): 223-27, 1972.

4. - Vicente-Chandler, J., and Abruña, F., Effect of four levels of fertilization on Beef Production and Carrying capacity of Pangola grass pastures in the humid mountain region of Puerto Rico, J. Agr. Univ. P.R. 56(3): 219-22, 1972.

5. - - Vicente-Chandler, J., and Figarella, J., The yield and composition of five grasses growing in the Humid Mountains of Puerto Rico as affected by nitrogen fertilization, season and harvest procedure, J. Agr. Univ. P.R. 44 (3): 107-20, 1960.

6. Vicente-Chandler, J., Caro-Costas, R., Pearson, R. W., Abruña, F., Figarella, J., and Silva, S., Intensive Management of Tropical Forages in Puerto Rico, Agr. Exp. Sta., Univ. P.R., Bull. 187, 152 pp., 1964.

7. - , and Figarella, J., The effect of five nitrogen sources on yield and composition of Napier grass, J. Agr. Univ. P.R. 46(2): 102-6, 1962.

8. - Figarella, J., and Silva, S., Effects of nitrogen fertilization and frequency of cutting on the yield and composition of Pangola grass in Puerto Rico, J. Agr. Univ. P.R. 45(1): 37-45, 1961.

9. - Silva, S., and Figarella, J., The effect of nitrogen fertilization and frequency of cutting on the yield of : I, Napier grass, II, Guines grass, and III, Para grass, J. Agr. Univ. P.R. 43(4): 215-48, 1959.

10. - Silva, S., Abruña, F., and Rodríguez, J., The effect of two cutting heights, four harvest intervals and five nitrogen rates on yield and composition of Congo grass under humid tropical conditions, J. Agr. Univ. P.R., 56(3): 280-91, 1972.

11. - Silva, S., and Figarella, J., The effect of nitrogen fertilization and frequency of cutting on the yield and composition of three tropical grasses, Agron. J. 51: 202-6, 1959.

12. —-, Silva, S., and Figarella, J., Effect of frequency of application on response of Guines grass to nitrogen fertilization, J. Agr. Univ. P.R. 46(4) : 342-9, 1962. 